\title{
BOVINE MEAT HAMBURGER WITH CHIA MIXED FLOUR, OATS AND LINSEED
}

\author{
Marcia Alves Chaves ${ }^{1 *}$; João Marcos Alves da Silva ${ }^{1}$, Alice Cristina Vettorello Geniake ${ }^{1}$, Eduardo \\ Cavalcante Dourado ${ }^{1}$, Mayara Patricia de Oliveira Santos ${ }^{1}$, Eliana Maria Baldissera ${ }^{1}$ \\ ${ }^{1}$ Food Department, UniversidadeTecnológica Federal do Paraná, 85884-000, Medianeira-PR, Brazil \\ *marcia_alves_chaves@hotmail.com
}

Submitted at 09/03/2018 and accepted at 05/04/2018

\begin{abstract}
The work aimed at developing formulations of hamburger using the chia mixed flour, oats and linseed, as a partial replacement to textured soy protein (PTS), commonly used in this product. Income analyzes, instrumental color and sensory analysis, were carried out indicating that the addition of $3 \%$ of the mixed flour reduced the loss of water after baking, indicating the probable contribution of the fibers present in the seed used for the preparation of flour for moisture retention in the product. Regarding color, significant differences $(p<0.05)$ between the
\end{abstract}

burgers were identified only in instrumental analysis, not being noticed by the sensory panelists. For sensory analysis, only the taste and texture attributes were significantly different, with higher averages for the formulation added to mixed flour, which contributed to the high levels of acceptability, above $70 \%$. It highlights the possibility of product preparation adding new ingredients, examples of the chia mixed flour, oats and linseed, however there is a need for further analysis to characterize the hamburger.

KEYWORD: Yeld; meat products; sensory analysis.

\section{HAMBÚRGUER DE CARNE BOVINA COM FARINHA MISTA DE CHIA, AVEIA E LINHAÇA}

\section{RESUMO}

O trabalho teve por objetivo desenvolver formulações de hambúrguer utilizando à farinha mista de chia, aveia e linhaça (F2), em substituição parcial a proteína texturizada de soja (PTS), comumente utilizada neste produto. Foram realizadas as análises de rendimento, cor instrumental e análise sensorial, indicando que a adição de $3 \%$ da farinha mista reduziu a perda de água após o assamento, indicando a provável contribuição das fibras da farinha para retenção de umidade no produto. Quanto à cor, foram identificadas diferenças significativas $(\mathrm{p}<0,05)$ entre os hambúrgueres somente na análise instrumental, não sendo perceptível pelos julgadores sensorialmente. Para análise sensorial, apenas os atributos sabor e textura foram diferentes significativamente, com maiores médias para F2, o que contribuiu para os elevados índices de aceitabilidade, acima de $70 \%$. Conclui-se a possibilidade de elaboração deste produto adicionado de novos ingredientes, contudo há a necessidade de mais análises para caracterizar o hambúrguer.

PALAVRAS CHAVE: Rendimento; produtos cárneos; análise sensorial. 


\section{INTRODUCTION}

According to the Normative Instruction number 20 of 2000, the burger is defined as an industrialized meat product obtained from minced meat of animals for slaughter, added or not adipose tissue and other ingredients, molded and submitted to appropriate technological process, where the texture, color, taste and smell must be characteristic (BRAZIL, 2000).

As mentioned by Arisseto (2003), this product has become highly attractive and popular due to the mode of life that are installed in urban centers, using a concept of feeding practice and easy to prepare. However, when submitted to the process of frying and overeating, the consumption of hamburger can cause injury to health due to the high amount of saturated fat present in processed food. In this way, consumers are also becoming increasingly aware about the composition of fat in the human diet and the development of cardiovascular diseases, causing them to seek alternatives in burgers that have better nutritional quality in their composition (HOFFMAN et al., 2005; LIMA et al., 2000).

Considering the evident search for quick and easy food preparation, research bodies and the food industry are investing in the development of new products which, in addition to meet this demand, may offer benefits for the consumers health (OLIVEIRA et al., 2013). Thus, the use of new ingredients in food formulations has been appearing as a strong market trend, the example of functional foods, which as Costa and Rosa (2006) have been increasingly incorporated the habits of the population.

Among these functional ingredients, some seeds have attracted the attention of researchers, among them, the chia, linseed and oats which have constituted a significant fraction of fibers between other components beneficial to health. According to Ceres (2008) oats is constituted by high protein contents and significant amount of dietary fiber with hypo-cholesterol action and acting in the reduction of cholesterol. The chia seeds, in turn, are mentioned by Peiretti and Gai (2009) as a food with a high content of $\alpha$-linolenic acid (omega-3) and linoleic acid (omega-6), antioxidants, dietary fiber and protein, while the linseed is a source of $\alpha$-linolenic fatty acid (52\% of total fatty acids), phenolic compounds and soluble fiber (SIMBALISTA et al., 2003; RAFTER, 2002).

According to Oliveira et al. (2013), the burger is one of the most studied meat products as the influence of the addition of fibers in the reduction of fat. However, further investigations are still necessaryin order to direct the development of formulations that meet the technological aspects, aiming juiciness and tenderness of the product at the same time that presents good sensory characteristics.

In this context, the objective of this work was to develop formulations of burger, with partial replacement of textured soy protein (PTS), commonly used in traditional formulations, by chia mixed flour, oats and linseed and perform the analyzes of yield after cooking, determination of color and sensory evaluation of the developed products.

\section{LITERATURE REVIEW}

\subsection{Funcional Foods}

The term functional food, initially proposed in Japan in the decade of 1980 encompasses the foods that are consumed as part of the diet that, beyond the provision of basic nutrients, present benefits for the metabolic and physiologic function, culminating in improvements in physical and mental health and preventing chronic diseases- degenerative (ANGELIS, 2001). In Brazil, there is no classification of functional foods, since the legislation based on Resolution number 18 of April 
30, 1999, lays down guidelines for the determination of functional properties claim or health of foods and ingredients for human consumption (BRAZIL, 1999).

Vidal et al. (2012), emphasizes that the consumption of functional foods do not cure diseases, it only prevent their occurrence and if this happens, it helps the body to more effectively fight them. These should not be used as remedies but incorporated in the diet so that can be consumed daily, helping the body to become stronger.

In this sense, the Brazilian legislation describes claim of ownership as that concerning the role of metabolic or physiological effect that the nutrient or non-nutrient has on growth, development, maintenance and other normal functions of the human body. For ownership of health, the legislation specifies the one that suggests or implies the existence of a relationship between the food or food ingredient with the disease or condition related to health (BRAZIL, 1999).

Confident in the increase of this segment of the market, Vidal et al. (2012), have scored for the announced awareness activity in the industrial sectors of food aiming at the development of healthier products and natural, once that in countries such as Japan, the United States and in Europe, many functional foods are already industrialized.

In Brazil, the production of these foods is still small and the permission for marketing of products with claims of functional property must be granted by the National Health Surveillance Agency (ANVISA), which will judge the safety and efficacy of the same based on a series of scientific documentation submitted by interested companies (SALLES, 2013).

According to Bascho and Bin (2012), various foods have already proven, and many others are being surveyed regarding their attributes which can assign an improvement in quality of life, promoting aid in disease prevention and health maintenance in a general way. To Nitzke (2012), between the substances allowed by law and that feature functional claim of ownership are the omega-3 fatty acids and dietary fiber and beta-glucan, fruto-oligosaccharides, dextrin resistant, guar gum, syrup, lactulose, polydextrose, psyllium and chitosan being that some of these components are present many seeds.

The linseed (Linum usitatissimum L.) presents in its composition, high content of lipids highlighting itself as one of the main sources of omega- 3 fatty acids responsible for acting in the prevention of cardiovascular diseases, hypertension and inflammatory disorders (SILVA, 2013). Also features such as active component the lignanas that can prevent and control cancer as the breast and lung (THOMPSON et al., 1991).

Considered one of the highest vegetative sources of linolenic fatty acid, the chia (Salvia hispanica L.), in addition to having as main component the omega-3 also has fibers in its composition and protein in significant quantities (TOSCO, 2004). These seeds are also rich in antioxidants and mineral salts as magnesium, phosphorus, selenium, potassium, especially calcium $(385 \mathrm{mg} / 100 \mathrm{~g})$ and iron $(11.98 \mathrm{mg} / 100 \mathrm{~g})$, sources of fibers $(34.6 \mathrm{~g} / 100 \mathrm{~g})$ and proteins (about $23 \mathrm{~g} / 100 \mathrm{~g}$ ), presenting all the essential amino acids (USDA, 2017).

The oats (Avena sativa L) provides significant amounts of protein, unsaturated fatty acids and vitamins, which have beneficial properties both functional and physiological and technological (SGARBIERE; PACHECO 1999; MARQUES, 2007). The fiber of oats as a substitute for fat in meat products has shown positive results in relation to income and also the texture of meat derived (KEETON, 1994; YILMAZ; DAGHOGLU, 2003). 


\subsection{Hamburger Production, Consumption and Characteristics}

To Oliveira et al. (2013), meat products are important sources of protein, fat, essential amino acids, minerals and vitamins. For this reason, the demand for these products is constantly increasing, placing Brazil as one of the largest producers and consumers of beef in the world. According to data from the Ministry of Agriculture, Livestock and Food Supply (MAPA) in 2017 it was estimated a production of 8.831 thousand tons of bovine carcass in the country with a per capita consumption of $34.4 \mathrm{~kg} / \mathrm{inh} a b i t a n t / y e a r$ (MAPA, 2018).

According to the information of the Brazilian Association of Industries Supply (ABIA) in the year 2015 perishable foods that grew the most in the country were industrialized meat, including sausages $(6.7 \%)$ and the frozen meat as frozen meals, hamburgers, tempered chicken cuts, with growth of $4.8 \%$ (ABIA, 2016).

In a study conducted by Kantar World panel, specialist in consumer behavior, the burger is included in the group of 20 categories of products under development, present in 40 to $70 \%$ of Brazilian households (ABIA, 2016). According to Paulino (2012) the consumption of hamburger is associated to the varieties of commercial presentation, by the wide range of price, expansion of networks of fast foods and by the fact that the consumer increasingly seeks convenience.

However, despite the convenience of preparation and its peculiar flavor, the hamburgers and other meat products do not have in their composition the fiber fraction, an important component for the health of the body, which when absent has led to the emergence of diseases of the digestive tract (TERRA et al., 2003).

The fibers in addition to acting directly on health, also contribute to the improvement in the characteristics of the meat products in the formation of gels, water retention or lipids, increase in the viscosity, formation and stabilization of emulsions and foams (CUMMINGS; STEPHEN, 2007). In this way, many researches have been directed to develop formulations of burger adding ingredients with possible contributions in improving the nutritional quality of these products. For Trevisan et al. (2016), new meat products of easy preparation and with healthy appeal have been elaborated to satisfy consumers looking for convenience coupled with the reduction in levels of fat and salt. For this reason, new ingredients are also tested to cause less impact on the texture, yield and other physio-chemical properties of these products.

Among the carried-outstudies, the work of Machado (2014) held the burger supplementation with quinoa flour with the aim of improving the nutritional quality of this product. Carvalho (2015) observed that the addition of wheat fiber in the maximum proportion of $3 \%$ can be viable in the substitution of fat in the burger with increase in satiety of the consumer. For Trevisan et al., (2016) there was a reduction of $35 \%$ in the level of fat as used up to $6 \%$ of fiber of oats in burger, being this proportion of oats used in other studies, the example of Marques (2007) which detected best grades in sensory analysis of burger with addition of $6.25 \%$ of fiber of oats in relation to formulating control.

Observing these searches, it is highlighted the importance of seeking new sources of ingredients that can improve the nutritional and sensorial quality in meat products, making them accessible to the general population. According to Basho and Bin (2012), insert functional foods that present a low cost for consumption are measures that can be adopted even by low-income people, having as a consequence a reduction in the incidence of chronic-degenerative diseases. 


\section{MATERIAL AND METHODS}

\subsection{Material}

For the development of formulations of burger, the ingredients were purchased in local commerce in the city of Medianeira-PR, these being: minced meat, textured soy protein (PTS), eggs, onions, carrots, salt, spices (bay leaf, fine herbs and pepper), oat flakes and grains of linseed and chia.

\subsection{Methods}

\subsubsection{Preparation of mixed flour}

To determine the concentrations of each ingredient in the preparation of the chia mixed flour, oats and linseed, pre-tests were performed and after setting the percentage of the same (chia: $0.8 \%, 1.1 \%$ and oats: linseed: $1.1 \%$ ) the ingredients were crushed separately in multiprocessor (model Viva $600 \mathrm{~W}$ series 125053341, Philips brand) to obtain a fine powder, being subsequently mixed until complete homogenization. The flour was wrapped in aluminum foil and wrapped in plastic packaging of high density polyethylene, previously hygienic with sodium hypochlorite (200 $\mathrm{mg} / \mathrm{L})$.

\subsubsection{Development of hamburguer formulations}

In preparation of the burger the percentage of the ingredients prior to tests was defined on a pilot scale, considering the profile of income and the sensory attributes of the formulations. It was developed a control formulation added to PTS (5.3\%) and a formulation with partial replacement of this ingredient by chia mixed flour, oats and linseed in the proportion of $3 \%$ plus $2.3 \%$ more of the PTS.

The ingredients were weighed and mixed in cutter equipment (model Master Curter R.i 12.000, RefereInox brand) to form a consistent emulsion, being added in the following order: ground beef of fore with low fat $(73.7 \%)$, PTS hydrated in $200 \mathrm{~mL}$ of water for 20 minutes $(5.3 \%)$, eggs $(4.2 \%)$, onion $(7.9 \%)$, carrot $(7.4 \%)$, salt $(1.1 \%)$, fine herbs $(0.2 \%)$, pepper $(0.1 \%)$ and bay leaf $(0.1 \%)$. In the formulation added to mixed flour, it was decided to add it $(3.0 \%)$ after adding the PTS $(2.3 \%)$. For the molding of the formulations of burger, the mixture was divided into individual portions with approximate mass of $80 \mathrm{~g}$, modeled in the burger shape with $10 \mathrm{~cm}$ in diameter, being wrapped in plastic trays of high density polyethylene and subjected to freezing in upright freezer ($18^{\circ} \mathrm{C} \pm 1^{\circ} \mathrm{C}$ ) for $24 \mathrm{~h}$. Once this period of time was over, the burgers were baked in oven (model Hot Grill 10537-13367, Fisher brand) at $180{ }^{\circ} \mathrm{C}$ for 30 minutes and subjected to analysis in triplicate. The drafting of the mixed flour and formulations of hamburgers were performed in the Laboratory of Technology of Meat and derivatives at the Universidade Tecnológica Federal do Paraná, campus of Medianeira-PR.

\subsubsection{Analyzes of the formulations of the hamburguer}

Yield calculation. Weighing was performed prior to freezing and subsequent cooking burger formulations according to the methodology described by Berry (1992).

Determination of color. In order to check the coloration of hamburgers with the addition of mixed flour, the instrumental evaluation of color was performed with the aid of a Minolta 
colorimeter (model Chroma Metter CR-400s, Konica Minolta brand). The color parameters evaluated were luminosity $\left(L^{*}, 100\right.$ for white and 0 for black) and chromaticity coordinates of the $\mathrm{CIE}$ system/LAB $\left[a^{*}(-)\right.$ to green and red $(+) ; b^{*}(-)$ to and blue to yellow (+); with illuminant D65 and $45^{\circ}$ angle)]. Three measurements were performed in different parts of the same formulation of burger and then calculated the average of each triplicate.

Sensory analysis. A total of 80 untrained panelists were recruited. The two formulations of burger, previously coded with random digits, were served at the same time in the amount of approximately $25 \mathrm{~g}$. The evaluation was performed in individual cabin under white light, located in the Sensory Analysis Laboratory of the Universidade Tecnológica Federal do Paraná, campus Medianeira. The acceptance test used was the hedonic scale of 9 points, where "9" corresponded to "liked very much" and "1" to "disliked very much" being evaluated the attributes color, odor, flavor, texture and global impression (FARIA; YOTSUYANAGI, 2008). Also proceeded with the test of purchase intent, using a structured scale of 5 points, where "5" was certainly buy and " 1 "corresponded to "certainly not buying". It was calculated the index of acceptability, according to Teixeira, Meinert and Barbetta (1987).

Statistical analysis. The averages of the triplicate samples were subjected to analysis of variance and when a significant difference at the 5\% level of probability was detected, the Tukey test was applied through the Statistic program, version 7.0 (STATSOFT, 2004).

\section{RESULTS AND DISCUSSION}

The results of the analyzes of income and instrumental color of burger formulations can be seen in Table 1.

Table 1- Results of the yeld analysis and instrumental color the formulations of the hamburger

\begin{tabular}{ccccc}
\hline Formulations* $^{*}$ & Yeld (\%) & $L$ & Cor & $b$ \\
\hline F1 & $56.35^{\mathrm{b}} \pm 0.57$ & $39.53^{\mathrm{a}} \pm 0.93$ & $3.40^{\mathrm{a}} \pm 0.11$ & $16.41^{\mathrm{b}} \pm 0.25$ \\
F2 & $65.07^{\mathrm{a}} \pm 1.78$ & $37.55^{\mathrm{b}} \pm 0.45$ & $3.10^{\mathrm{b}} \pm 0.10$ & $17.50^{\mathrm{a}} \pm 0.30$ \\
\hline
\end{tabular}

*F1: Formulation control (5.3\% of PTS) F2: Formulation added chia mixed flour, oats and flaxseed (3.0\%). Average followed by the same letter, in the same column do not differ by Tukey test $(\mathrm{p}<0.05)$ at a significance level of $5 \%$.

The yield of the burger is of great value, because it affects the amount in weight of the product after cooking, it is important that the same hold its shape and reduce syneresis with the heating process. In addition, the absorption of water in meat products influences the sensory quality of the burger because the moisture loss in cooking can harm the juiciness and the softness of these products (BERTRAM; ANDRESEN; KARLSSON, 2001). It was observed that the formulation control (F1) differed from F2, presenting greater loss of water, being that in F1 there was a reduction of $8.72 \%$ of the mass of the hamburger in relation to $\mathrm{F} 2$, demonstrating that the addition of mixed flour of chia, linseed and oats, can absorb moisture better, due to the levels of fibers in its composition and consequently reduce the weight loss by cooking.

Studies conducted by Almeida (2011) in goat burger added of 4\% oat flour and Silva (2013) in a beef burger with different proportions of linseed flour (2,5 to $10 \%)$ showed similar results to the present work, being that the yield has increased to the extent that were high quantities of these flours. Still, Trevisan et al. (2016) considered the fiber of oats as an ingredient promising to assist 
formulations of meat products with reduced salt and fat, the addition of this resulted in a reduction in weight loss during the heating in addition to improve the color stability during storage under freezing for 60 days.

Another factor to be considered is regarding the type of meat used in the preparation of these products, because, in the literature we found studies that used different cattlecuts in preparation of hamburgers, which also reflects in different results of yield after cooking, due to the distinct water retention capacity of each one of these cuts.

Regarding the color, it should be noted that there was a significant difference $(p<0.05)$ for the parameters analyzed, demonstrating the influence of mixed flour in the coloration of burgers, since the grains of flaxseed and chia, used as raw material of flour have brown color. However, this aspect was not observed in the sensory evaluation, since the judges did not observe differences in the attribute color of formulations of burger. Still, it appears that both samples have low luminosity, demonstrating that the burgers formulated have dark tone, which is primarily influenced by the tone of the meat, since the value of the $a^{*}$ remained positive, indicating the predominance of red color. The parameter $b^{*}$ also presented positive values for the two formulations, demonstrating that the burgers had yellow hue due to the processing of cooking.

Regarding the sensory analysis, the results can be observed in Table 2 which shows the rates of the attributes color, odor, flavor, texture and global impression of formulations of burger.

Table 2- Results of sensory analysis by hedonic scale of the formulations of the hamburger

\begin{tabular}{|c|c|c|c|c|c|}
\hline Formulations* & Color & Odor & $\begin{array}{l}\text { Attributes } \\
\text { Flavor }\end{array}$ & Texture & $\begin{array}{c}\text { Global } \\
\text { evaluation }\end{array}$ \\
\hline F1 & $6.62^{\mathrm{a}} \pm 1.64$ & $7.05^{\mathrm{a}} \pm 1.56$ & $7.20^{b} \pm 1.29$ & $7.09^{b} \pm 1.46$ & $7.09^{\mathrm{a}} \pm 1.22$ \\
\hline $\mathrm{F} 2$ & $7.08^{\mathrm{a}} \pm 1.68$ & $7.01^{\mathrm{a}} \pm 1.64$ & $7.70^{\mathrm{a}} \pm 1.11$ & $7.56^{\mathrm{a}} \pm 1.37$ & $7.47^{\mathrm{a}} \pm 1.42$ \\
\hline
\end{tabular}

*F1 Formulation control (5.3\% of PTS) F2: Formulation added chia mixed flour, oats and flaxseed (3.0\%). Average followed by the same letter, in the same column do not differ by Tukey test $(\mathrm{p}<0.05)$ at a significance level of $5 \%$.

As seen in Table 2, note that for color, odor and overall impression there were no significant differences $(\mathrm{p}<0.05)$ among the formulations, corroborating with Rocha $(2015)$, which did not identify significant differences in formulations of burger added pea fiber regarding the control sample, for all evaluated attributes. These results are important from a technological point of view, once the color has great impact on the overall impression, being one of the items evaluated by the consumer for the acquisition of a particular food. It appears that the addition of mixed flour (chia, linseed and oats) did not influence the decision of the judges regarding the coloration of burgers, being this important result for the incorporation of these new ingredients in meat products.

For the flavor and texture, there was a significant difference at the level of $5 \%$ significance between the formulations. It should be noted that, for both attributes, the formulation added to mixed flour obtained the highest averages, placing itself in the hedonic scale between the terms "moderately liked" and "liked very much". These results are seen as positive, in function of the mixed flour have not changed the taste of the product, because it is known that the oil content in the composition of the grains of chia and linseed and its high content of fatty acids omegas 3 and 6 have sharp flavor and which could be transferred to the burgers. 
For texture, the result is likely to have relationship with the technological characteristics of the burger, in particular to the retention of water, generating a three-dimensional network insoluble, which may have contributed to the tenderness and juiciness, reported by some judges in F2. Trevisan et al. (2016) also did not observe differences in the texture of chicken burger added oats.

Even though the proportion of flour of chia has been less than $1 \%$, it is estimated that this percentage is feasible in elevation in the levels of omega- 3 in the formulation 2 and may add improvements in nutritional quality of this product, benefiting those who practice its consumption. In a study conducted by Gohara et al. (2015), the flour of chia increased levels of poly-unsaturated fatty acids, especially alpha-linolenic acid, which composes the series $n-3$, in burger with addition of chia defatted flour.

All the attributes analyzed showed higher index of acceptability to a minimum $(70 \%)$ proposed by Teixeira, Meinert e Barbetta (1987). For all attributes evaluated, the formulation added to mixed flour obtained higher rates of acceptance, demonstrating that there is space for the incorporation of new ingredients that may contribute to improving nutrition in food.

In relation to purchase intention, the results for F1 and F2 were $3.58 \pm 0.98$ and $4.16 \pm$ 0.84 , respectively, corresponding to the scale of perhaps and probably buy. These results meet the high level of acceptability observed mainly in the formulation added to mixed flour, demonstrating the possibility of these products be purchased, if they were available in the market.

\section{CONCLUSION}

The results indicate the possibility in the development of the burger with addition of mixed flour of chia oats, and linseed in the proportion of 3,0\% since, its percentage of acceptability was greater than $70 \%$ for all attributes evaluated, having higher averages than the control formulation as to the flavor and texture are evaluated. The color was significant only in instrumental analysis, do not indicating differences in the sensory evaluation. Another factor of interest is yield, therefore, the addition of mixed flour reduced the loss of water, keeping the product with greater mass after cooking when compared to the control formulation. In this way, it becomes necessary to conduct further research, emphasizing the physio-chemical characterization of burgers in an attempt to quantify the nutrients besides studying other tracks of addition of mixed flour and assess its performance on the instrumental texture.

\section{REFERENCES}

ASSOCIAÇÃO BRASILEIRA DAS INDÚSTRIAS DA ALIMENTAÇÃO (ABIA). Com disputa entre marcas, cresce venda de congelados e industrializados. February $24^{\text {th }}, 2016$. Available in: < http://www.abia.org.br/vsn/tmp_2.aspx?id=167\#sthash.CHZmJ9ai.dpbs>. Access in February 20 ${ }^{\text {th }}, 2018$.

ALMEIDA, Rudinei Silva. Processamento de hambúrguer de carne caprina adicionados com diferentes níveis de farinha de aveia. 73 f. Dissertação (Mestrado em Zootecnia)-Universidade Estadual do Sudoeste da Bahia. ItapetiningaBA, 2011.

ANGELIS, Rebeca Carlota de. Importância de alimentos vegetais na proteção da saúde: fisiologia da nutrição protetora e preventiva de enfermidades degenerativas. Rio de Janeiro: Atheneu, 2001. 295p. 
ARISSETO, Adriana Pavesi. Avaliação da qualidade global do hambúrguer tipo calabresa com reduzidos teores de nitrito. 145 f. Dissertação (Mestrado em Tecnologia de Alimentos)- Universidade Estadual de Campinas. Campinas-SP, 2003.

BASHO, S.M.; BIN, M.C. Propriedades dos Alimentos Funcionais e seu Papel na Prevenção e Controle da Hipertensão e Diabetes. Interbio, v.4, n.1, p,48-58, 2010.

BERRY, B. W. Low fat level effects on sensory, shear, cooking, and chemical properties of ground beef patties. Journal of Food Science, v.57, n.3, p.537-540, 1992.

BERTRAM, H.C.; ANDRESSEN, H.J; KARLSSON, A.H. Comparative study of low-field NMR relaxation measurements and two traditional methods in the determination of water holding capacity of pork. Meat Science, v.57, p. 125-132.

BRASIL. Agência Nacional de Vigilância Sanitária (ANVISA). Resolução no ${ }^{\circ}$ 18, de 30 de abril de 1999. Aprova o Regulamento Técnico que estabelece as diretrizes básicas para análise e comprovação de propriedades funcionais e ou de saúde alegadas em rotulagem de alimentos, constante do anexo desta portaria. Diário Oficial da União, Brasília-DF 03 de maio de 1999.

BRASIL. Ministério da Saúde. Institui o Regulamento Técnico de Identidade e Qualidade do Hambúrguer. Instrução Normativa $n^{\circ} 20$ de 16 de junho de 2000. Diário Oficial da República Federativa do Brasil. Brasília-DF, 03 de agosto de 2000 .

CARVALHO, Larissa Tátero. Parâmetros tecnológicos, aceitação sensorial e sensação de saciedade após o consumo de hambúrguer bovino com adição de fibra de trigo e teor de gordura reduzido. 75 f. Dissertação (Mestrado em Engenharia de Alimentos)-Universidade de São Paulo. Pirassununga-SP, 2015.

COSTA, N. M. B.; ROSA, C. O. B. Alimentos Funcionais. Viçosa: Folha de Viçosa, 2006.

CUMMINGS, J.H.; STEPHEN, A.M. Carbohydrate terminology and classification. European Journal of Clinical Nutrition, v.61, p.5-18, 2007.

FARIA, E. V.; YOTSUYANAGI, k. Técnicas de análise sensorial. 2. ed. Campinas: Ital., 2008. 120 p.

GOHARA, A.A.; SOUZA, A.H.P.de.; GOHARA, A.K.; MATSUSHITA, M.; GOMES, S.T.M. Efeito da Adição de Farinha Parcialmente Desengordurada de Chia (Salvia hispanica L.) na Composição de Ácidos Graxos em Hambúrguer. In: XXI EAIC e IV EAIC Jr. 23 a 25 de setembro de 2015. Maringá-PR.

HOFFMAN, L. C.; JOUBERT, M.; BRAND, T. S.; MANLEY, M. The effect of dietary fish oil rich in $\mathrm{n}-3$ fatty acids on the organoleptic, fatty acid and physicochemical characteristics of ostrich meat. Meat Science, v.70, n.1, p.45-53, 2005 .

KEETON, J. T. Low-fat meats products technological problems with processing. Meat Science, v. 36, n.1, p. 261-276, 1994.

LIMA, F. E. L.; MENEZES, T.N.de.; TAVARES, M.P.; SZARFARC, S.C.; FISBERG, R.M. Ácidos graxos e doenças cardiovasculares: uma revisão. Revista de Nutrição, v.13, n.2, p.73-80, 2000.

MACHADO, Elisandrea Aparecida. Avaliação da Qualidade Nutricional de Hambúrgueres Suplementados com Farinha de Quinoa. 40 f. Monografia (Curso Superior em Tecnologia de Alimentos)-Universidade Tecnológica Federal do Paraná. Francisco Beltrão -PR, 2014.

MARQUES, Jocilene de Miranda. Elaboração de um Produto de carne Bovina "Tipo Hambúrguer" Adicionado de Farinha de Aveia. 71 f. Dissertação (Mestrado em Tecnologia de Alimentos)-Universidade Federal do Paraná. Curitiba, PR, 2007.

MINISTÉRIO DA AGRICULTURA PECUÁRIA E ABASTECIMENTO (MAPA). Complexo Carnes. 31/01/2018. Disponível em:< http://www.agricultura.gov.br/assuntos/politica-agricola/todas-publicacoes-de-politicaagricola/sumarios-executivos-de-produtos-agricolas/carnes-1.pdf/view >. Acesso em 18/02/2018.

NITZKE, Julio Alberto. Alimentos Funcionais: Uma Análise Histórica e Conceitual. Curitiba : Appris, 2012. p.11-23.

SILVA, Carlos Eduardo da. Elaboração e Avaliação de Hambúrgueres de Carne com Substituições de Toucinho por Farinha de Linhaça. 54 f. Dissertação (Mestrado Profissional em Tecnologia de Alimentos)-Universidade Tecnológica Federal do Paraná, Londrina-PR, 2013. 
OLIVEIRA, D. F.de.; COELHO, A.R.; BURGARDT, V.de.C.da F.; HASHIMOTO, E.H.; LUNKES, A.M.; MARCHI, J.F.; TONIAL, I.B. (2013). Alternativas para um produto cárneo mais saudável: uma revisão. Brazilian Journal Food Technology, v.16, n.3, p.163-174, 2013.

PAULINO, Flavia de Oliveira. Produção e características de qualidade de hamburguer de carne de jacaré-do-pantanal (Caiman crocodilos yacare). 100 f. Tese (Doutorado)- Universidade Federal Fluminense, Niteroi, 2012.

PEIRETTI, P. G.; GAI, F. Fatty acid and nutritive quality of chia (Salvia hispanica L.) seeds and plant during growth. Animal Feed Science and Technology, v.148, p.267-275, 2009.

RAFTER, Joseph. Scientific Basic of biomarkers and benefis of funcional foods for reduction of disease risk: cancer. British Journal and Nutrition, v.88 n.2, p. 219-224, 2002.

ROCHA, Yana Jorge Polizer. Aplicação de Fibra de Ervilha em Produtos Cárneos. 69 f. Dissertação (Mestrado em Ciências)- Faculdade de Zootecnia e Engenharia de Alimentos. Universidade de São Paulo. Pirassununga, 2015.

SALLES, Leonardo Gaspary. Os Alimentos Funcionais no Brasil. 109 f. Monografia (Curso Superior em Ciências Sociais)-Universidade Federal de Santa Catarina. Florianópolis-SC, 2013.

SGARBIERI, V.C.; PACHECO, M.T.B. Revisão: alimentos funcionais fisiológicos. Brazilian Journal Food and Technology, v.2, n.1-2, p.7-19, 1999

SIMBALISTA, R.L.; CAPRILLES, V.D.; ARÊAS, J.A.G. Caracterização da semente de linhaça (Linux isitatissimim)B. In: Anais do $7^{\circ}$ Congresso da Sociedade Brasileira de Alimentação e Nutrição, Belo Horizonte, MG, 2003.

STATSOFT INC. Statistica data analysis system version 7.0. Tulsa: Statsoft Inc., 2004.

TEIXEIRA, E.; MEINERT, E. M.; BARBETTA, P. Análise sensorial de alimentos. Florianópiolis: Ed UFSC, 1987.

TERRA, N. N. et al. A carne e os benefícios da fibra alimentar. Revista Nacional da Carne. n. 311, janeiro 2003.

THOMPSON, L.U.; CHEN, J.M.; LI, T.; STRASSER-WEIPPL, K.; GOSS, P.E. Dietary Flaxssed Alters Tumor Biological Markers in postmenoupausal Breast Cancer. Clinical Cancer Research. v. 11, n. 1, p. 3828-3835. 2005.

TOSCO, G. Os Benefícios da “Chia” em Humanos e Animais. Atualidades Ornitológicas, n. 119, p. 7, 2004.

TREVISAN, Y.C.; BIS, C.V.; HENCK, J.M.; BARRETO, A.C.S.da. Efeito da adição de fibra de aveia sobre as propriedades físico-químicas de hambúrguer cozido e congelado com redução de gordura e sal. Brazilian Journal Food and Technology, v.19, p.1-8, 2016.

YILMAZ, I.; DAGHOGLU, O. The effect of replacing fat with oat bran on fatty acid composition and physicochemical properties of meatballs. Meat Science, v. 65, n. 2, p. 819-823, 2003.

UNITED STATES DEPARTMENT OF AGRICULTURE (USDA). Whole chia seeds. July 14, 2017. Disponível em:< https://ndb.nal.usda.gov/ndb/foods/show/24607?manu=\&fgcd=\&ds= > . Acesso em February 15, 2018

VIDAL, A.M.; DIAS, D. O.; MARTINS, E.S.M.; OLIVEIRA, R.F.; NASCIMENTO, R.M.S.; CORREIA, M.G.S. da. A ingestão de alimentos funcionais e sua contribuição para a diminuição da incidência de doenças. Cadernos de Graduação, v. 1, n.15, p. 43-52, 2012. 